\title{
Inpatient Profile of Patients with Major Depression in Portuguese National Health System Hospitals, in 2008 and 2013: Variation in a Time of Economic Crisis
}

\author{
Daniel Francisco Santos Rodrigues ${ }^{1} \cdot$ Carla Nunes $^{2}$
}

Received: 2 May 2016 / Accepted: 28 April 2017

(c) Springer Science+Business Media New York 2017

\begin{abstract}
The economic crisis has placed Portugal in a situation of budgetary constraints with repercussions on mental health, since 2009. This study analyses the association between economic crisis and the inpatient profile of major depression in the working-age population in Portuguese National Health System hospitals. This was an observational, descriptive and cross-sectional study. An individual analysis of hospitalisation and an ecological analysis at district level, were performed before 2008 and during the crisis (2013). Data on the hospitalisation episodes, working-age population and psychiatric inpatient beds were analysed. An increase in hospitalisation rates for major depression were observed, and across country, high spatial variations were perceived: districts with lower rates of urbanisation and population density had higher hospitalisation rates for major depression. Hospitalisation rates were positively influenced by the available inpatient beds. The results for 2013 were more critical (higher hospitalisation rates, less beds). Further research is needed to understand all patterns, considering other individual and contextual information.
\end{abstract}

Keywords Depression · Economic crisis · Inpatient · Accessibility $\cdot$ Utilisation $\cdot$ Health services

Carla Nunes

cnunes@ensp.unl.pt

1 Psychiatry Department, Hospital Vila Franca de Xira, Estrada Nacional 1, Povos, 2600-009 Vila Franca de Xira, Portugal

2 Escola Nacional de Saúde Pública e Centro de Investigação em Saúde Pública, Universidade NOVA de Lisboa, Av. Padre Cruz, 1600-560 Lisboa, Portugal

\section{Introduction}

Mental illness significantly affects peoples' quality of life, and is responsible for a huge economic impact on society, which highlights the need for an organised response and allocation of human, material and financial resources for the magnitude of the problem (Dlouhy 2014).

A growing knowledge base shows the effects of economic crises on health but these effects vary between countries and between population subgroups in each country (Marmot and Bell 2009; Marmot 2014; OPSS 2012; Stuckler et al. 2011) and are influenced by the tax policy of the country or by the presence of social security systems and effective health networks that could determine the risk magnitude of the health problems (Marmot 2014).

The economic crises affect the determinants of mental health by weakening the protective factors and strengthening the risk factors. The scientific evidence regarding the current economic and financial crisis and its impact on mental health is still scarce, but some studies have shown the impact of past economic crises (Chang et al. 2009; Reeves et al. 2012).

Factors like household indebtedness, unemployment and impoverishment are potentiated in times of economic crisis and play a crucial role in the development of mental illnesses (Jenkins et al. 2008; Reading and Reynolds 2001; Skapinakis et al. 2006; Taylor et al. 2007; WHO 2011) predisposing people to a higher risk of mental health problems such as major depression, alcohol consumption and suicide (Dee 2001; Dooley et al. 1994; Dorling 2009; Lewis and Sloggett 1998; Mathers and Schofield 1998; McKee-Ryan et al. 2005; Murphy and Athanasou 1999).

An increased suicide rate is the most visible indicator of the impact of an economic crisis on health, but scientific research also demonstrates a significant increase in 
major depression and anxiety (Costa et al. 2012; Economou et al. 2013; Gili et al. 2013; Katikireddi et al. 2012). Furthermore, a significant number of suicides occur in people with major depression and the economic crisis, especially unemployment, can act as a triggering factor (Butterworth et al. 2009; Chang et al. 2009; Reeves et al. 2012; Stuckler et al. 2011).

In Portugal, the unemployment rate has registered a continuous increase, from $7.6 \%$ in 2008 to $16.3 \%$ in 2013 (INE 2014a) and based on available data, in the past 5 years (2008-2012) the suicide mortality rate has undergone slight variations, standing at about 10 suicides per 100,000 inhabitants (DGS 2014; INE 2014b). However, according to the Portuguese Observatory on Health Systems (OPSS), it is suspected that there is a strong underreporting of suicides, which may be clarified in the coming years due to the implementation of a death certificate computerised system (SICO) which will contribute to the analysis of the suicide rate in Portugal (OPSS 2014).

In 2013, Xavier et al. (2013) defined the contextual situation as a high prevalence of mental illness scenario with extremely unfavourable social determinants of health, exacerbated by the scientific research deficit in the mental health sector, especially regarding care delivery, organisational structures and epidemiological data (Xavier et al. 2013).

Beyond the impact of the economic crisis on mental health, there also occurs an increase in demand for health services, especially psychiatric health services, and this increase is exacerbated by health expenditure reduction policies, promoted by governments in times of economic crisis, which places the mental health sector in a weaker position than other health sectors (Hong and Heok 2009; Marmot and Bell 2009).

The reduction in the health budget can have negative effects on the adequacy of health resources, especially when unemployment and poverty increase the pressure on health systems and, according to the WHO, the countries hardest hit by the economic crisis decreased by approximately half the budget allocated to the health sector (WHO 2013).

The aim of this study is to analyse the association between the economic crisis and the hospitalisation profile for major depression in the working-age population in NHS hospitals in Portugal, at national level and at district level (18 geographic units). The specific objectives are to characterise the hospitalisation profile for major depression of the working-age population, by geographical area for 2008 and 2013; analyse if the hospitalisation rate for major depression of the working-age population varies in an economic crisis period (2013) in contrast with a precrisis period (2008) and analyse if the hospitalisation rate for major depression of the working-age population is influenced by the rate of inpatient beds available in 2008 and 2013.

The ground-breaking nature of this work is to understand association of the economic crisis with the hospitalisation profile for major depression in the working-age population, trying to understand if profiles and inpatient bed availability changed, not only at national scale, but also characterising these variations within country.

\section{Methods}

This was an epidemiological, observational, descriptive and cross-sectional study, using two different approaches, in the years 2008 and 2013: (1) an individual analysis mainly focused on patient characteristics (sex, age, comorbidities and place of residence) achieved through the analysis of hospitalisation episodes for major depression; (2) and an ecological analysis at district level, considering demographic characteristics (sex and age of population), number psychiatric beds available, and hospitalisation for major depression.

The study population is the working-age population, aged more than 15 years and not exceeding 64 years, resident in Portugal, who had at least one episode of hospitalisation in NHS hospitals. Assuming that all cases of hospitalisation episodes are reported at national level, there was no sampling process applied to this study.

\section{Data Collection}

Data on the hospitalisation episodes, working-age population and psychiatric inpatient beds were analysed. We used the official dataset of hospitalisation episodes (ACSS 2014), which contains data regarding the inpatient and outpatient NHS hospital production; workingage population data from Statistics Portugal; and data on the number of available psychiatric inpatient beds provided by the Directorate-General of Health in the years 2008 and 2013.

From the official database of hospitalisation episodes, admissions related to working-age population (15-64 years old) were selected, corresponding to 850,086 hospitalisation episodes $(46.26 \%$ of total episodes of hospitalisation) for the years 2008 and 2013.

The definition of hospitalisation for major depression adopted in this study included episodes in which the main diagnosis or, in the absence of main diagnosis, the first secondary diagnosis corresponded to a diagnosis of major depression. 


\section{Statistical Analysis}

As already stated, this study has two components (individual and ecological) with different goals. Initially, at the individual level a general characterisation of the inpatient hospitalisation profile for major depression in the working-age population in NHS hospitals in Portugal was performed by geographical area for the years 2008 and 2013. Following a descriptive approach and focus on the dichotomy of hospitalisation for major depression (event under study) and non-major depression (all other hospitalisations) we used Chi square tests of independence, considering sociodemographic variables (gender, age group and place of residence) and clinical (presence of comorbidities) variables. The magnitude of the association between risk factors and the dependent variable (binary variable: hospitalization for major depressionyes/no) was calculated based on odds ratio (OR) crude and adjusted (for gender and age) through binary logistic regression models (method: enter, function: logit).

In the second component, in order to analyse if the hospitalisation rate for major depression of the working-age population is influenced by the rate of inpatient beds available in 2008 and 2013, an ecological study was developed at district level (18 units), using descriptive statistics, correlation coefficients and linear regression methods.

Statistical analyses were performed using software Excel (Microsoft Excel, v. 2013) and the Statistical Package for Social Sciences (SPSS, v. 20), both in versions for Windows. A 5\% significance level was assumed.
Ethics committee approval and informed consent were not required, as data was based on an Official Dataset and was previously anonymised. The authors declare that they have no conflict of interest. All authors certify responsibility.

\section{Results}

In agreement with the "Methods" section, results are presented in two sections: individual and ecological level.

\section{Individual Analysis Results}

Table 1 shows the distribution of the hospital admission population, globally and stratified by hospitalisation for major depression (Yes/No), according to the variables gender, age group and comorbidity presence, in both periods.

The relative frequency of hospitalisation for major depression was higher among females in both periods, and in 2013, an increased relative frequency of hospitalisation for major depression in males is observed. In both periods, it is observed that the 45-54 years old age group had the highest relative frequency of hospitalisations for major depression.

The relative frequency of hospitalisations for major depressive disorders in the presence of comorbidities increased from $0.3 \%$ in 2008 to $0.4 \%$ in 2013 .

At district level in 2008, the minimum relative frequency of hospitalisations for major depression observed was 0.1 , with a mean of 0.54 , a standard deviation of 0.3 and a
Table 1 Comparative analysis of study population distribution, by gender, age group and comorbidities presence

\begin{tabular}{|c|c|c|c|c|c|c|}
\hline & \multicolumn{3}{|l|}{$2008^{\mathrm{a}}$} & \multicolumn{3}{|l|}{$2013^{\mathrm{a}}$} \\
\hline & \multirow[t]{2}{*}{$\begin{array}{l}\text { Total hospitali- } \\
\text { zations [n (\%)] }\end{array}$} & \multicolumn{2}{|c|}{$\begin{array}{l}\text { Hospitalizations for major } \\
\text { depression }\end{array}$} & \multirow[t]{2}{*}{$\begin{array}{l}\text { Total hospitali- } \\
\text { zations [n (\%)] }\end{array}$} & \multicolumn{2}{|c|}{$\begin{array}{l}\text { Hospitalizations for major } \\
\text { depression }\end{array}$} \\
\hline & & Yes [n (\%)] & No $[\mathrm{n}(\%)]$ & & Yes [n (\%)] & No [n (\%)] \\
\hline \multicolumn{7}{|l|}{ Total } \\
\hline $\mathrm{n}(\%)$ & $426,994(100)$ & $1711(0.4)$ & $425,283(99.6)$ & $383,105(100)$ & $1696(0.4)$ & $381,409(99.6)$ \\
\hline \multicolumn{7}{|l|}{ Gender } \\
\hline Male & $162,558(38.1)$ & $503(0.3)$ & $162,055(99.7)$ & $153,679(40.1)$ & $545(0.4)$ & $153,134(99.6)$ \\
\hline Female & $264,436(61.9)$ & $1208(0.5)$ & $263,228(99.5)$ & $229,426(59.9)$ & $1151(0.5)$ & $228,275(99.5)$ \\
\hline \multicolumn{7}{|l|}{ Age group } \\
\hline$[15-24]$ & $48,638(11.4)$ & $93(0.2)$ & $48,545(99.8)$ & $38,332(10.0)$ & $84(0.2)$ & $38,248(99.8)$ \\
\hline$[25-34]$ & $103,453(24.2)$ & $251(0.2)$ & $103,202(99.8)$ & $77,778(20.3)$ & $209(0.3)$ & $77,569(99.7)$ \\
\hline$[35-44]$ & $82,341(19.3)$ & $441(0.5)$ & $81,900(99.5)$ & $75,859(19.8)$ & $398(0.5)$ & $75,461(99.5)$ \\
\hline$[45-54]$ & $87,735(20.5)$ & $484(0.6)$ & $87,251(99.4)$ & $83,670(21.8)$ & $523(0.6)$ & $83,147(99.4)$ \\
\hline [55-64] & $104,827(24.5)$ & $442(0.4)$ & $104,385(99.6)$ & $107,467(28.1)$ & $482(0.4)$ & $106,985(99.6)$ \\
\hline \multicolumn{7}{|c|}{ Comorbidities presence } \\
\hline Yes & $230,188(53.9)$ & $676(0.3)$ & $229,512(99.7)$ & $129,006(33.7)$ & $569(0.4)$ & $128,437(99.6)$ \\
\hline No & $196,806(46.1)$ & $1035(0.5)$ & $195,771(99.5)$ & $254,099(66.3)$ & $1127(0.4)$ & $252,972(99.6)$ \\
\hline
\end{tabular}


maximum of 1.7. In 2013 the corresponding values were $0.1,0.56,0.33$ and 1.2 respectively. Figure 1 shows the relative frequencies of hospitalisations for major depression at district level (place of residence) in both periods.

Table 2 presents the analysis of crude and adjusted OR (by gender and age) of the hospitalisation rates by major depression in both periods. In order to observe spatial variation across the country, Fig. 2 shows crude odds ratios. Lisbon district (A), capital of Portugal, was used as the reference class.

In agreement with previous results, it is observed that the risk of hospitalisation for major depression is higher in women, in the age groups of 45-54 and 35-44 years old and without comorbidities, in both periods. At geographical level we can observe huge variations (Crude odds ratios: in 2008 range $=0.28-4.40$, mean $=1.38$ and standard deviation $=0.97$; in 2013, respectively, 0.35-3.26, 1.56, 0.85), more evident in the centre-south of Portugal (in both spatial and temporal perspectives).

\section{Ecological Analysis Results}

In order to evaluate the potential pertinence of contextual variables in hospitalisation for major depression rates (namely the socio-demographic patterns of local populations and number of psychiatric beds available), an ecological analysis was developed. Considering working-age population by place of residence-districts, Table 3 shows the frequencies and some descriptive statistics of gender and age groups in both periods.

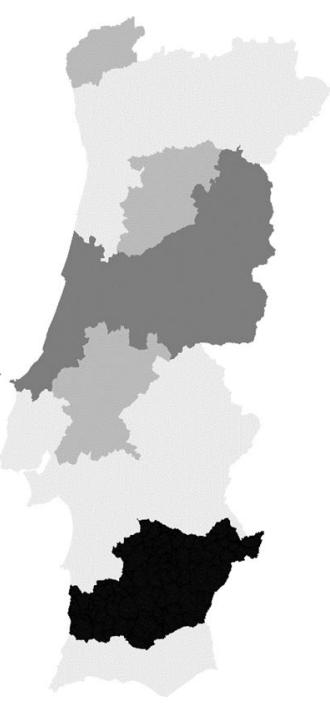

(a) 2008

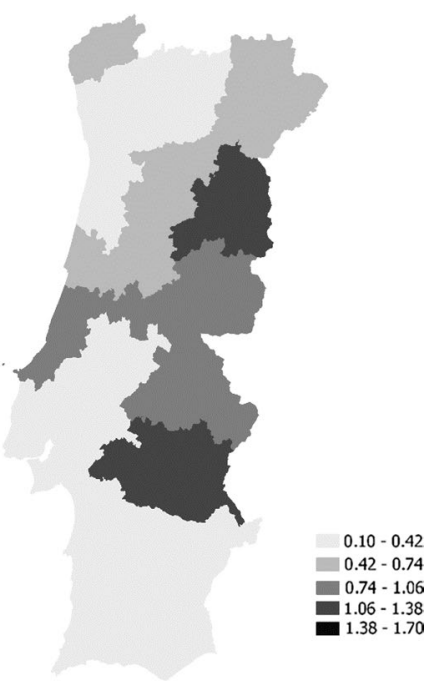

(b) 2013
Fig. 1 Relative frequencies of hospitalizations for major depression at district level (place of residence), in both periods
The working-age population decreased between 2008 $(n=6,683,416)$ and $2013(n=6,481,463)$. The relative frequency of female gender was slightly higher than male gender in both periods. In 2008, the age group 35-44 years old has the highest relative frequency, followed by the age groups 45-54 and 25-34 years old. The age groups 55-64 and 15-24 years old have lower relative frequencies. In 2013, the age group 45-54 years has the highest relative frequency. The age groups 25-34 and 15-24 years old have a lower relative frequency. Based on descriptive statistics, namely range and standard deviation, it seems that there is no evidence of huge variations in sex-age patterns at district level.

At national level the average hospitalisation rates for major depression is 25.60 in 2008 , and 26.17 per 100,000 inhabitants of the working-age population in 2013. On the other hand, the average inpatient bed rate available was 17.58 in 2008 , and 16.65 per 100,000 inhabitants of the working-age population in 2013.

Table 4 shows the correlation between the rate of available inpatient beds, the hospitalisation rate for major depression and the relative frequencies by age and gender of the working-age population in both periods at district level. Table 5 presents linear regression models for hospitalisation rate for major depression of the working-age population, developed at district level.

In 2008, the relative frequency of population in the age group 45-54 years old has a moderate positive correlation and is statistically significant with the inpatient bed rate and the hospitalisation rate for major depression; and the relative frequency of population in the age group 55-64 years old has a strong positive correlation, statistically significant with the inpatient bed rate, while with the hospitalisation rate for major depression the correlation is positive and significant but moderate. Finally, the hospitalisation rate for major depression has a moderate positive and statistically significant correlation with the inpatient bed rate.

Relative to the year of 2013, the relative frequency of population in the age group 45-54 years old has a moderate positive correlation, statistically significant with the inpatient bed rate and the hospitalisation rate for major depression; and the relative frequency of population in the age group 55-64 years old has a strong positive, statistically significant correlation with the inpatient bed rate, and moderate positive, statistically significant correlation with the hospitalisation rate for major depression. Finally, the hospitalisation rate for major depression has a moderate positive and statistically significant correlation with the inpatient bed rate.

In both periods, the inpatient bed rate influences the hospitalisation rate by major depression, for each additional inpatient bed there is an increase of about $1(B=1.050$, $p=0,043$ ) hospitalisation in 2008; and an increase of about 
Table 2 Crude and adjusted odds ratio for hospitalizations for major depression

\begin{tabular}{|c|c|c|c|c|}
\hline & \multicolumn{2}{|l|}{2008} & \multicolumn{2}{|l|}{2013} \\
\hline & OR (IC 95\%) & Adjusted OR ${ }^{\mathrm{a}}$ (IC 95\%) & OR (IC 95\%) & Adjusted OR ${ }^{\mathrm{a}}(\mathrm{IC} 95 \%)$ \\
\hline \multicolumn{5}{|c|}{ Gender (male: reference class) } \\
\hline Female & $1.613(1.449 ; 1.795)$ & - & $1.602(1.442 ; 1.779)$ & - \\
\hline \multicolumn{5}{|c|}{ Age group (55-64: reference class) } \\
\hline $15-24$ & $0.360(0.287 ; 0.452)$ & - & $0.448(0.354 ; 0.566)$ & - \\
\hline $25-34$ & $0.433(0.369 ; 0.508)$ & - & $0.508(0.429 ; 0.600)$ & - \\
\hline $35-44$ & $1.094(0.957 ; 1.251)$ & - & $1.074(0.938 ; 1.230)$ & - \\
\hline $45-54$ & $1.235(1.085 ; 1.406)$ & - & $1.373(1.212 ; 1.555)$ & - \\
\hline \multicolumn{5}{|c|}{ Comorbidities presence (no: reference class) } \\
\hline Yes & $0.516(0.467 ; 0.570)$ & $0.505(0.458 ; 0.558)$ & $0.896(0.808 ; 0.994)$ & $0.931(0.840 ; 1.032)$ \\
\hline \multicolumn{5}{|c|}{ Place of residence (Lisbon: reference class) } \\
\hline Aveiro & $0.642(0.503 ; 0.818)$ & $0.650(0.510 ; 0.829)$ & $0.640(0.490 ; 0.836)$ & $0.641(0.491 ; 0.837)$ \\
\hline Beja & $4.398(2.939 ; 6.583)$ & $4.611(3.082 ; 6.897)$ & $1.098(0.691 ; 1.747)$ & $1.098(0.690 ; 1.746)$ \\
\hline Braga & $0.276(0.194 ; 0.393)$ & $0.277(0.195 ; 0.394)$ & $0.347(0.252 ; 0.477)$ & $0.348(0.253 ; 0.478)$ \\
\hline Bragança & $0.759(0.493 ; 1.170)$ & $0.851(0.553 ; 1.312)$ & $1.827(1.309 ; 2.551)$ & $1.829(1.310 ; 2.553)$ \\
\hline Castelo Branco & $2.194(1.733 ; 2.778)$ & $2.303(1.820 ; 2.916)$ & $2.309(1.803 ; 2.956)$ & $2.309(1.803 ; 2.956)$ \\
\hline Coimbra & $2.148(1.783 ; 2.588)$ & $2.133(1.771 ; 2.570)$ & $1.809(1.466 ; 2.232)$ & $1.808(1.465 ; 2.231)$ \\
\hline Évora & $1.030(0.695 ; 1.527)$ & $1.140(0.769 ; 1.688)$ & $3.259(2.505 ; 4.240)$ & $3.252(2.500 ; 4.231)$ \\
\hline Faro & $0.780(0.552 ; 1.100)$ & $0.836(0.592 ; 1.179)$ & $0.741(0.537 ; 1.023)$ & $0.742(0.537 ; 1.023)$ \\
\hline Guarda & $2.050(1.567 ; 2.683)$ & $2.241(1.714 ; 2.932)$ & $2.766(2.088 ; 3.663)$ & $2.756(2.080 ; 3.650)$ \\
\hline Leiria & $2.246(1.870 ; 2.697)$ & $2.282(1.901 ; 2.740)$ & $2.381(1.973 ; 2.875)$ & $2.378(1.970 ; 2.871)$ \\
\hline Portalegre & $0.597(0.296 ; 1.204)$ & $0.619(0.307 ; 1.248)$ & $2.405(1.694 ; 3.414)$ & $2.403(1.693 ; 3.412)$ \\
\hline Porto & $0.717(0.604 ; 0.850)$ & $0.706(0.595 ; 0.838)$ & $0.786(0.665 ; 0.930)$ & $0.793(0.671 ; 0.938)$ \\
\hline Santarém & $1.805(1.479 ; 2.204)$ & $1.875(1.536 ; 2.288)$ & $2.034(1.665 ; 2.486)$ & $2.030(1.661 ; 2.480)$ \\
\hline Setúbal & $0.990(0.807 ; 1.214)$ & $1.068(0.871 ; 1.310)$ & $1.150(0.933 ; 1.419)$ & $1.152(0.934 ; 1.422)$ \\
\hline Viana do Castelo & $1.173(0.866 ; 1.589)$ & $1.276(0.942 ; 1.728)$ & $1.239(0.904 ; 1.700)$ & $1.238(0.903 ; 1.697)$ \\
\hline Vila Real & $0.826(0.583 ; 1.172)$ & $0.917(0.647 ; 1.300)$ & $0.517(0.291 ; 0.921)$ & $0.519(0.291 ; 0.924)$ \\
\hline Viseu & $1.242(0.973 ; 1.586)$ & $1.256(0.983 ; 1.603)$ & 1.715 (1.346; 2.184) & $1.723(1.352 ; 2.194)$ \\
\hline
\end{tabular}

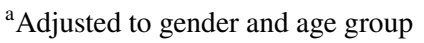

$1(B=1.260, p=0,019)$ hospitalisation in 2013 by major depression per 100,000 inhabitants of the working-age population.

\section{Discussion}

Economic crises cause impoverishment, insecurity and unemployment, with repercussions on people's health, specifically mental health. Mental health has been the most sensitive area to economic changes, and in periods of economic crisis there is an increase in the number of cases of major depression and the number of relapses. As stated by Xavier et al. (2013), this is a period of high prevalence of mental illness, with extremely unfavourable social health determinants and numerous unmet needs in terms of health services, health care delivery and epidemiological research in the mental health sector (Caldas-de-Almeida and Xavier 2013).
In this work, the selection of the study population-the working-age population, aimed to contribute to the knowledge of the impact of the economic crisis on one of the population subgroups more vulnerable to these phenomena because of the exposure to unemployment, loss of income and indebtedness, as suggested by the literature. Observing the distribution of hospitalisation episodes through the official dataset allows the analyses of the entire study population, enhancing the credibility of the results.

\section{Gender}

The analysis of the inpatient profile for major depression has shown that the relative frequency of hospitalisations for major depression is higher for females in both periods. Additionally, an increased relative frequency of hospitalisations in males in 2013 was also observed. There is a strong consensus in national and intrenational literature, that women have a significantly higher risk than men of 


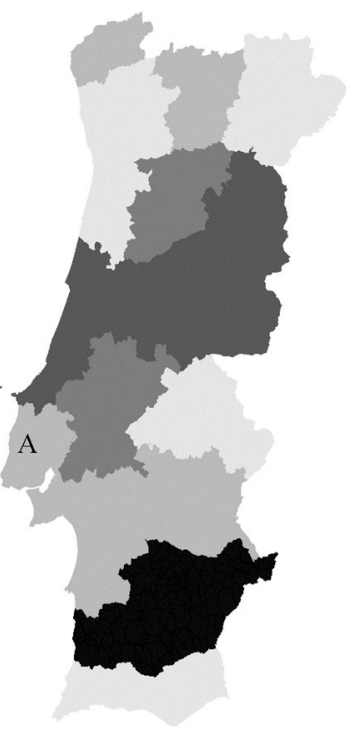

(a) 2008

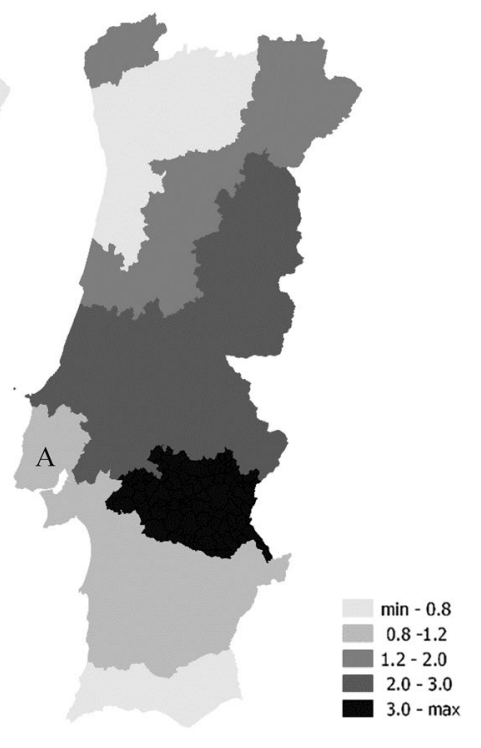

(b) 2013
Fig. 2 Crude odds ratio for major depression hospitalization, by district [reference class-Lisbon $(A)$ ], for both periods

developing major depression at some point in life (Caldasde-Almeida and Xavier 2013; Alonso et al. 2004; Bebbington et al. 2003; Paul; Bebbington 1996; Briscoe 1982; Fryers et al. 2005; Jenkins 1985; Munce and Stewart 2007; Nolen-Hoeksema 1987; Weissman and Klerman 1977). Nevertheless, it should be highlighted that the incidence in males in 2013 was higher than in 2008, and it can be reasonable to suspect that the impact of common risk factors (for instance unemployment) can be more severe in males (socially and financially).

\section{Age Group}

As for the age group of the individuals hospitalised for major depression there were no significant differences between the 2 years. The age group with the highest relative frequency of hospitalisation for major depression is the $45-54$ years old $(0.6 \%)$, with crude ORs of 1.2 times in 2008 and 1.4 times in 2013, compared with the age group 55-64 years old (reference class). This result is also supported by the ecological approach, being observed that in both years, the relative frequency of population in the younger age groups of the working-age population has a negative moderate correlation with the hospitalisation rate for major depression, while the relative frequency of population in the age groups of 45-54 and 55-64 years old presents moderate and strong positive correlations, respectively, with the hospitalisation rate for major depression in both periods.

In Portugal, according to the EENSM (2013), older age groups are less likely to suffer depressive disorders, noting that the age groups 18-34 years old $(\mathrm{OR}=2.18), 35-49$ years old $(\mathrm{OR}=2.11)$ and $50-64$ years old $(\mathrm{OR}=1.82)$ have a higher risk of suffering from depressive disorders than the age group of the population aged over 65 years (Caldas-de-Almeida and Xavier 2013). Thus, comparing both studies, we may suspect that individuals in older age
Table 3 Descriptive analysis of working-age population distribution, by gender and age group at district level, per year

\begin{tabular}{lllllll}
\hline & Total N (\%) & Mean & Median & $\begin{array}{l}\text { Standard } \\
\text { deviation }\end{array}$ & Min & Max \\
\hline 2008 & & & & & & \\
Male N (\%) & $3,268,889(48.91)$ & 49.37 & 49.29 & 0.77 & 48.23 & 51.56 \\
Female N (\%) & $3,414,527(51.09)$ & 50.63 & 50.71 & 0.77 & 48.44 & 51.77 \\
[15-24] N (\%) & $1,116,151(16.70)$ & 16.78 & 16.77 & 0.69 & 15.77 & 18.57 \\
[25-34] N (\%) & $1,459,321(21.84)$ & 21.14 & 21.17 & 1.19 & 18.75 & 23.08 \\
[35-44] N (\%) & $1,499,386(22.43)$ & 21.95 & 21.82 & 0.85 & 20.10 & 23.47 \\
[45-54] N (\%) & $1,396,902(20.90)$ & 21.55 & 21.52 & 0.93 & 19.79 & 23.37 \\
{$[55-64]$ N (\%) } & $1,211,656(18.13)$ & 18.59 & 18.76 & 1.35 & 14.99 & 20.84 \\
Total N (\%) & $6,683,416(100)$ & & & & & \\
2013 & & & & & & \\
Male N (\%) & $3,146,648(48.55)$ & 49.09 & 48.98 & 0.83 & 47.91 & 51.46 \\
Female N (\%) & $3,334,815(51.45)$ & 50.91 & 51.02 & 0.83 & 48.54 & 52.09 \\
{$[15-24]$ N (\%) } & $1,043,094(16.09)$ & 16.06 & 15.92 & 0.70 & 14.96 & 17.62 \\
{$[25-34]$ N (\%) } & $1,203,993(18.58)$ & 18.08 & 18.05 & 0.76 & 16.53 & 19.52 \\
{$[35-44]$ N (\%) } & $1,518,680(23.43)$ & 22.63 & 22.93 & 1.27 & 20.31 & 24.69 \\
{$[45-54]$ N (\%) } & $1,439,238(22.21)$ & 22.67 & 22.83 & 0.86 & 20.65 & 24.21 \\
[55-64] N (\%) & $1,276,458(19.69)$ & 20.56 & 20.38 & 1.50 & 17.68 & 23.61 \\
Total N (\%) & $6,481,463(100)$ & & & & & \\
\hline
\end{tabular}


Table 4 Correlations between the working-age population variables (gender, age group), inpatients beds and hospitalization rate for major depression, at district level, per year

\begin{tabular}{|c|c|c|c|c|c|c|c|}
\hline & {$[15-24]$ years $(\%)$} & {$[25-34]$ years $(\%)$} & {$[35-44]$ years $(\%)$} & {$[45-54]$ years $(\%)$} & {$[55-64]$ years $(\%)$} & Male $(\%)$ & Inpatient beds ${ }^{\mathrm{a}}$ \\
\hline \multicolumn{8}{|l|}{2008} \\
\hline \multicolumn{8}{|l|}{ Male $(\%)$} \\
\hline Pearson & 0.070 & -0.424 & -0.354 & 0.491 & 0.223 & \multicolumn{2}{|l|}{1} \\
\hline P-value & 0.783 & 0.079 & 0.150 & $\mathbf{0 . 0 3 8}$ & 0.373 & & \\
\hline \multicolumn{8}{|c|}{ Inpatient beds $\mathrm{s}^{\mathrm{a}}$} \\
\hline Pearson & -0.331 & -0.488 & -0.526 & 0.469 & 0.610 & 0.020 & \multirow[t]{2}{*}{1} \\
\hline P-value & 0.180 & 0.040 & 0.025 & $\mathbf{0 . 0 5 0}$ & 0.007 & 0.936 & \\
\hline \multicolumn{8}{|c|}{ Hospitalizations for major depression ${ }^{\mathrm{b}}$} \\
\hline Pearson & -0.388 & -0.514 & -0.325 & 0.485 & 0.524 & 0.035 & 0.481 \\
\hline P-value & 0.112 & 0.029 & 0.189 & 0.041 & 0.026 & 0.891 & 0.043 \\
\hline \multicolumn{8}{|l|}{2013} \\
\hline \multicolumn{8}{|l|}{ Male $(\%)$} \\
\hline Pearson & -0.128 & -0.398 & -0.558 & 0.488 & 0.453 & \multirow[t]{2}{*}{1} & \\
\hline P-value & 0.612 & 0.102 & 0.016 & 0.040 & 0.059 & & \\
\hline \multicolumn{8}{|c|}{ Inpatient beds ${ }^{\mathrm{a}}$} \\
\hline Pearson & -0.348 & -0.601 & -0.563 & 0.414 & 0.704 & 0.131 & \multirow[t]{2}{*}{1} \\
\hline P-value & 0.157 & 0.008 & 0.015 & 0.088 & 0.001 & 0.606 & \\
\hline \multicolumn{8}{|c|}{ Hospitalizations for major depression ${ }^{\mathrm{b}}$} \\
\hline Pearson & -0.422 & -0.501 & -0.404 & 0.376 & 0.576 & 0.293 & 0.546 \\
\hline P-value & 0.081 & 0.034 & 0.096 & 0.124 & 0.012 & 0.239 & 0.019 \\
\hline
\end{tabular}

Statistical significant results are presented in bold

${ }^{a}$ Inpatient beds: Inpatient beds rate for the treatment of major depression (1/100,000 inhabitants), in the working-age population

${ }^{\mathrm{b}}$ Hospitalizations for major depression: inpatient hospitalizations rate by major depression (1/100,000 inhabitants), in the working-age population

Table 5 Linear regression model

\begin{tabular}{|c|c|c|c|c|c|c|}
\hline & \multirow[t]{2}{*}{ Year } & \multirow[t]{2}{*}{ B } & \multirow[t]{2}{*}{ Std. error } & \multirow[t]{2}{*}{ Sig. } & \multicolumn{2}{|c|}{$95.0 \%$ confidence interval for B } \\
\hline & & & & & Lower bound & Upper bound \\
\hline \multirow[t]{2}{*}{ Inpatient beds ${ }^{\mathrm{a}}$} & 2008 & 1.05 & 0.479 & 0.043 & 0.035 & 2.064 \\
\hline & 2013 & 1.26 & 0.484 & 0.019 & 0.235 & 2.285 \\
\hline \multirow[t]{2}{*}[55-64]{ years $^{b}$} & 2008 & 7.592 & 3.085 & 0.026 & 1.051 & 14.132 \\
\hline & 2013 & 7.812 & 2.771 & 0.012 & 1.937 & $13 ., 686$ \\
\hline
\end{tabular}

${ }^{a}$ Inpatient beds: inpatient beds rate for the treatment of major depression (1/100,000 inhabitants), in the working-age population

b [55-64] years: relative frequency of working-age population in age group [55-64] years old groups of the working-age population, although less likely to have depressive disorders, can potentially obtain easier access to hospitalisation for major depression or have severe forms of major depression. The analysis of this phenomenon is important in future investigations.

\section{Comorbidities}

There is evidence that the risk of major depression increases with the presence of comorbidities and vice versa (Akhtar-Danesh and Landeen 2007; Gusmão and Xavier
2005), so it was expected that the number of hospitalisations for major depression in the presence of comorbidities would be higher, which was not observed here. It is observed that the relative frequency of hospitalisation for major depression with presence of comorbidities is only $0.3 \%$ in 2008 and $0.4 \%$ in 2013 . These results can be explained by a methodological option: for this work the definition of hospitalisation episodes for major depression were only considered as those in which the main diagnosis or, in the absence of main diagnosis, the first secondary diagnosis corresponded to a diagnosis of major depression. 
This methodological definition may, itself, have excluded a significant number of episodes of hospitalisation wherein major depression occurs.

\section{Place of Residence}

The literature suggests that the environment where people live can influence the incidence and prevalence of major depression (Kovess-Masféty et al. 2005; Sundquist et al. 2004; Wang 2004).

From the distribution of the hospitalisation rate for major depression analysis by place of residence, it was found that districts with reduced urbanisation rates and population density had higher hospitalisation rates, and residents in districts with these characteristics had a higher risk of hospitalisation for major depression in both periods. Comparing the years 2008 and 2013, we highlight the worsening risk profile of individuals living in districts predominantly located inland and a significant decrease in the risk of hospitalisation for major depression observed in individuals living in Beja (a district in the centre-south of Portugal: $\mathrm{OR}=4.611$ and $\mathrm{OR}=1.098$, in 2008 and 2013, respectively). The worsening risk profile in individuals living in districts predominantly located inland can be justified by rurality and some studies show that people in rural areas have a prevalence of major depression higher than that of the population in urban areas (Wang 2004). However, we cannot exclude the influence of other factors such as social isolation (Fryers et al. 2005; Laaksonen et al. 2007; WHO 2011), unemployment (Chen et al. 2012), and the number of inpatient beds available (Delamater et al. 2013; Fortney et al. 2007).

A significant decrease in the risk of hospitalisation for major depression seen in individuals living in Beja (centre-south), between 2008 and 2013 can be justified by the reduction in the number of inpatient beds available which occurred in the Centro Hospitalar Psiquiátrico de Lisboa (the corresponding psychiatric hospital), which resulted in a reduction from 17.66 (2008) to 13.98 (2013) psychiatric inpatient beds per 100,000 inhabitants of the working-age population living in Beja. Beja is the only district without local services and available offer (in Lisbon, $200 \mathrm{Km}$ distance) decrease between the two periods. This phenomenon is particularly relevant because a significant number of people with major depression could potentially not have reached the proper treatment due to proximity or accessibility limitations to health services and this needs more detailed investigation. Additionally, it should be noted that the proportion of users with mental disorders registered in the primary health care sector and the number of adult psychiatric consultations per 1000 inhabitants increased significantly between 2012 and 2013 (Caldas-de-Almeida and Xavier 2013).

\section{Hospitalisation Episode Rate Variation}

In 2008, there was an average rate of hospitalisation for major depression of 25.60 hospitalisations per 100,000 inhabitants of the working-age population, with significant spatial asymmetries and more critical patterns in the centre of Portugal and inland.

In 2013, the economic crisis period, the average rate of hospitalisation for major depression observed was higher than in 2008, 26.17 hospitalisations per 100,000 inhabitants of the working-age population, although with lower variation especially due to smaller extreme values.

The increase in hospitalisation rate for major depression seen in the economic crisis period can be explained by the increased incidence and prevalence of major depression. Indeed, there is ample evidence from previous economic crises showing that people affected by unemployment, impoverishment and family problems have a significantly higher risk of mental health problems such as major depression, suicide and problems related to alcohol consumption and psychoactive substances, than unaffected people (Blakely et al. 2003; Chang et al. 2009; Dee 2001; Dooley et al. 1994; Dorling 2009; Fryers et al. 2005; Gunnell et al. 1999; Lewis and Sloggett 1998; Mathers and Schofield 1998; McKee-Ryan et al. 2005; Murphy and Athanasou 1999).

The evolution of hospitalisation for major depression occurred, according to the EENSM (2013), and was also accompanied by an increase in hospitalisation in psychiatric units related to mental disorders induced by drugs in Portugal (2009-2013) (Caldas-de-Almeida and Xavier 2013).

Considering the time period under study, other indicators of serious mental health problems in the population can be stated: the suicide mortality rate between 2008 and 2012 in all regions of mainland Portugal increased (DGS 2014; INE 2014b). According to the literature, a significant portion of suicides during the economic crisis occurred in people with major depression and the economic crisis, especially unemployment, acts as precipitating factor (Butterworth et al. 2009; Chang et al. 2009; Reeves et al. 2012; Stuckler et al. 2011).

\section{Psychiatric Inpatient Beds}

The correlation between psychiatric inpatient beds and the hospitalisation rate for major depression of the working-age population was here well and positively identified as being influenced by the inpatient beds available, in both periods. Based on linear regression models, it was estimated that for each additional hospital bed, an increase of about 1 hospitalisation for major depression per 100,000 inhabitants of 
the working-age population occurs $(B=1.050$ in 2008 and $B=1.260$ in 2013).

These results can be explained by Roemer's law, according to which a health service has the ability to generate its own demand and existing evidence shows that variation in hospitalisation rates can be enhanced by the availability of inpatient beds and this relationship is observed at various geographical levels (Delamater et al. 2013; Fortney et al. 2007). It is important to remember that the economic crisis has acted as a catalyst for structural reforms, such as the implementation of measures to promote transparency in contracting (Freitas and Escoval 2010), the closure or merger of some hospitals and the primary focus on the service in ambulatory and primary health care (McDaid et al. 2013; OECD 2013; Quaglio et al. 2013).

In Portugal, the number of inpatient beds available for acute mental health care in NHS hospitals corresponds to the DGS ratio defined according to WHO recommendations from 1995 to 10 beds per 100,000 inhabitants (Caldas-de-Almeida and Xavier 2013). According to the ACSS (2014), the number of acute inpatient psychiatric beds decreased between $2008(n=1182)$ and $2013(n=1079)$, and this reduction explains the average number of inpatient beds available observed in this study, from 17.58 in 2008 , to 16.65 in 2013, psychiatric inpatient beds available per 100,000 inhabitants of the working-age population (ACSS 2014). Caldas-de-Almeida and Xavier (2013) argue that, despite the recent opening of two mental health services with inpatient units, there are still gaps in some hospitals to ensure the planned relocation of key population groups, especially the inactivity of the inpatient unit in Beja, and the lack of implementation of new inpatient units in the north of Portugal (Caldas-de-Almeida and Xavier 2013).

According to this study, if the hospitalisation rate for major depression has a moderate and positive correlation with the rate of inpatient bed availability, it would be expected that the hospitalisation rate between the 2 years, following the reduction of the inpatient beds available decreased, but the hospitalisation rate increased in 2013, which reinforces the association of the economic crisis with the hospitalisation rate for major depression, and suggests that reducing the inpatient beds available could negatively influence the hospitalisation rate for major depression in the working-age population.

The need for hospitalisation units may, however, have been offset by an increase in existing ambulatory structures, more rigid hospitalisation criteria and/or a more effective response in the primary health care sector (Caldas-de-Almeida and Xavier 2013).

According to EENSM (2013), there are other important factors to take into account when analysing the variation of the hospitalisation profile in times of economic crisis, as the increase in the registration of users with mental disorders in the primary health care sector can mean an increased accessibility to non-specialised services or may be associated with an increased demand for help in recent years related to depressive disorders (Caldas-de-Almeida and Xavier 2013). Furthermore, from 2000 to 2012, there was a clear increase in the consumption of antidepressant $(+240 \%)$ and antipsychotic (+171\%) drugs (INFARMED 2014).

This study has several limitations and it can only be viewed as an exploratory work. The geographical and temporal variation of major depression hospitalisation analysis in the working-age population was conditioned by the absence of data on the hospital outpatient basis production and the suicide mortality rate, among others, which can skew the results. For methodological issues, the ecological study, conditioned by the geographical availability of the necessary information was conducted at the district level, which implies the existence of only 18 observations and strongly influences the choice of statistical methods used and the validity of the results.

Despite these limitations, this study provides important insights regarding geographical and temporal variations of major depression hospitalisation analysis in the workingage population. The hospitalisation rate for major depression of the working-age population was higher in 2013. This study also noted that the hospitalisation rate and the risk of hospitalisation for major depression in males increased, though they remain higher in females, and the risk of hospitalisation increased in most districts during the economic crisis period. From the distribution analysis of hospitalisations for major depression by place of residence, it was found that districts with reduced urbanisation rates and population density had higher hospitalisation rates, and residents in districts with these characteristics had an increased risk of hospitalisation for major depression in both periods. The decreased inpatient bed rates and the increased hospitalisation rates in the economic crisis period, suggest that the observed variation could be higher if the available beds rate had not been reduced. Additionally, the association between the available bed rate and the hospitalisation rate was positively influenced by the economic crisis period reinforcing the hypothesis that reducing the available bed rate may have negatively influenced the variation in hospitalisation rate for major depression. Furthermore, there was an increased pressure on acute psychiatric inpatient services that was reflected in the increase in the number of hospitalisations for major depression per available bed in 2013 .

This information can be used to inform the development of health policies to address the impact of economic crises on the inpatient profile for major depression in the workingage population in NHS hospitals in Portugal. However, in order to increase scientific knowledge about the impact of 
the economic crisis on hospitalisation for major depression in Portugal, more research is needed using small geographical areas (municipalities or parish) including several areas, namely: incidence versus prevalence of major depression, mental health services proximity, hospital outpatient production and community care teams, psychotropic drugs consumption, poverty and unemployment.

The impact of the economic crisis on health services and specifically on mental health, challenges health systems and exposes their weaknesses. The high prevalence of mental illness in a context where health determinants are extremely unfavourable turns protection of mental health into a priority. The adoption of strategies to promote surveillance of health problems, the reassessment of priorities in public health and the evaluation of health policies with increased investment for the prevention and treatment of mental illness are essential.

Acknowledgements We acknowledge DGS for providing data on the number of available psychiatric inpatient beds for the years 2008 and 2013; ACSS for providing the official database of hospitalisation episodes; and Statistics Portugal for providing data on the workingage population.

\section{References}

ACSS. (2014). Camas disponíveis. ACSS, DPS, Sica 04-06-2014.

Akhtar-Danesh, N., \& Landeen, J. (2007). Relation between depression and sociodemographic factors. International Journal of Mental Health Systems, 1(1), 4. doi:10.1186/1752-4458-1-4.

Alonso, J., Angermeyer, M. C., Bernert, S., Bruffaerts, R., Brugha, T. S., Bryson, H., ... Vollebergh, W. A. M. (2004). Prevalence of mental disorders in Europe: Results from the European Study of the Epidemiology of Mental Disorders (ESEMeD) project. Acta Psychiatrica Scandinavica. Supplementum, 420, 21-27. Retrieved from http://search.ebscohost.com/login.aspx?direct=tr $\mathrm{ue} \& \mathrm{db}=$ mdc $\& \mathrm{AN}=15128384 \&$ lang $=$ pt-br $\&$ site $=$ ehost-live .

Bebbington, P. (1996). The origins of sex differences in depressive disorder: Bridging the gap. International Review of Psychiatry, $8(4)$, 295. Retrieved from http://search.ebscohost.com/login. asp $x$ direct $=$ true $\& d b=$ mdc $\& A N=E P T O C 9701093249 \&$ lang $=$ pt-br\&site $=$ ehost-live.

Bebbington, P., Dunn, G., Jenkins, R., Lewis, G., Brugha, T., Farrell, M., \& Meltzer, H. (2003). The influence of age and sex on the prevalence of depressive conditions: Report from the National Survey of Psychiatric Morbidity. International Review of Psychiatry (Abingdon, England), 15(1-2), 74-83. Retrieved from http://search.ebscohost.com/login.aspx?direct $=$ true $\& \mathrm{db}=\mathrm{mdc} \&$ AN=12745313\&lang=pt-br\&site=ehost-live.

Blakely, T. A., Collings, S. C. D., \& Atkinson, J. (2003). Unemployment and suicide. Evidence for a causal association? Journal of Epidemiology and Community Health, 57(8), 594-600. Retrieved from http://search.ebscohost.com/login.aspx?direct $=\mathrm{tr}$ ue $\& \mathrm{db}=$ mdc $\& A N=12883065 \&$ lang $=$ pt-br\&site $=$ ehost-live.

Briscoe, M. (1982). Sex differences in psychological well-being. Psychological Medicine Monograph Supplement, 1, 1-46. Retrieved from http://search.ebscohost.com/login.aspx?direct $=$ true $\& \mathrm{db}=\mathrm{m}$ dc\&AN=6954556\&lang $=$ pt-br\&site=ehost-live.
Butterworth, P., Rodgers, B., \& Windsor, T. D. (2009). Financial hardship, socio-economic position and depression: Results from the PATH Through Life Survey. Social Science \& Medicine, 69(2), 229-237. doi:10.1016/j.socscimed.2009.05.008.

Caldas-de-Almeida, J. M., \& Xavier, M. (2013). Estudo Epidemiológico Nacional de Saúde Mental, Lisboa.

Chang, S., Gunnell, D., Sterne, J. A. C., Lu, T., \& Cheng, A. T. A. (2009). Was the economic crisis 1997-1998 responsible for rising suicide rates in East/Southeast Asia? A time-trend analysis for Japan, Hong Kong, South Korea, Taiwan, Singapore and Thailand. Social Science \& Medicine, 68(7), 1322-1331. doi:10.1016/j.socscimed.2009.01.010.

Chen, L., Li, W., He, J., Wu, L., Yan, Z., \& Tang, W. (2012). Mental health, duration of unemployment, and coping strategy: A crosssectional study of unemployed migrant workers in eastern China during the economic crisis. BMC Public Health, 12(1), 597. doi:10.1186/1471-2458-12-597.

Costa, G., Marra, M., \& Salmaso, S. (2012). Health indicators in the time of crisis in Italy. Epidemiologia E Prevenzione, 36(6), 337-366. Retrieved from http://search.ebscohost.com/ login.aspx ?direct $=$ true $\& d b=$ mdc $\& A N=23293258 \&$ lang $=$ pt-br\&site $=$ ehost-live.

Dee, T. S. (2001). Alcohol abuse and economic conditions: evidence from repeated cross-sections of individual-level data. Health Economics, 10(3), 257-270. Retrieved from http://search.ebscohost.com/login. aspx $?$ direct $=$ true $\& d b=$ mdc $\& A N=11288191 \& l a$ ng $=$ pt-br\&site $=$ ehost-live

Delamater, P. L., Messina, J. P., Grady, S. C., WinklerPrins, V., \& Shortridge, A. M. (2013). Do more hospital beds lead to higher hospitalization rates? A spatial examination of Roemer's Law. PLoS ONE, 8(2), e54900-e54900. doi:10.1371/journal. pone. 0054900

DGS Direção de Serviços de Informação e Análise. (2014). Portugal: Saúde Mental em números, 2014. Retrieved from http://www. dgs.pt/estatisticas-de-saude/estatisticas-de-saude/publicacoes/ portugal-saude-mental-em-numeros-2014.aspx.

Dlouhy, M. (2014). Mental health policy in Eastern Europe: A comparative analysis of seven mental health systems. BMC Health Services Research, 14, 42. doi:10.1186/1472-6963-14-42.

Dooley, D., Catalano, R., \& Wilson, G. (1994). Depression and unemployment: Panel findings from the Epidemiologic Catchment Area study. American Journal of Community Psychology, 22(6), 745-765. Retrieved from http://search.ebscohost. com/login. asp ? direct $=$ true $\& d b=$ mdc $\& A N=7639201 \&$ lang $=$ pt-br\&site $=$ ehost-live.

Dorling, D. (2009). Unemployment and health. BMJ (Clinical Research Ed.), 338, b829-b829. doi:10.1136/bmj.b829.

Economou, M., Madianos, M., Peppou, L. E., Patelakis, A., \& Stefanis, C. N. (2013). Major depression in the era of economic crisis: A replication of a cross-sectional study across Greece. Journal of Affective Disorders, 145(3), 308-314. doi:10.1016/j. jad.2012.08.008.

Estudo Epidemiológico Nacional de Saúde Mental (EENSM). (2013). $1^{o}$ RELATÓRIO. http://www.fcm.unl.pt/main/alldoc/galeria_ imagens/Relatorio_Estudo_Saude-Mental_2.pdf.

Fortney, J., Rushton, G., Wood, S., Zhang, L., Xu, S., Dong, F., \& Rost, K. (2007). Community-level risk factors for depression hospitalizations. Administration and Policy in Mental Health, 34(4), 343-352. Retrieved from http://search.ebscohost.com/ login.aspx ?direct $=$ true $\& d b=$ mdc $\& A N=17294123 \&$ lang $=$ pt-br\&site $=$ ehost-live.

Freitas, P., \& Escoval, A. (2010). A transparência na contratualização em saúde eo papel dos cidadãos. Revista Portuguesa de Saúde Pública, 9, 129-140. Retrieved from http://www.ensp.unl.pt/dispositivos-de-apoio/cdi/cdi/sector-de-publicacoes/revista/2010/ pdf/volume-tematico-contratualizacao/EC-11-2009.pdf. 
Fryers, T., Melzer, D., Jenkins, R., \& Brugha, T. (2005). The distribution of the common mental disorders: Social inequalities in Europe. Clinical Practice and Epidemiology in Mental Health: $C P \& E M H, 1,14$. Retrieved from http://search.ebscohost. com/login. aspx ?direct $=$ true $\& d b=$ mdc $\& A N=16143042 \&$ lang $=$ pt-br\&site $=$ ehost-live.

Gili, M., Roca, M., Basu, S., McKee, M., \& Stuckler, D. (2013). The mental health risks of economic crisis in Spain: Evidence from primary care centres, 2006 and 2010. European Journal of Public Health, 23(1), 103-108. doi:10.1093/eurpub/cks035.

Gunnell, D., Lopatatzidis, A., Dorling, D., Wehner, H., Southall, H., \& Frankel, S. (1999). Suicide and unemployment in young people. Analysis of trends in England and Wales, 1921-1995. The British Journal of Psychiatry: The Journal of Mental Science, 175, 263-270. Retrieved from http://search.ebscohost. com/login.asp $\mathrm{x}$ direct $=$ true $\& d b=\mathrm{mdc} \& \mathrm{AN}=10645329 \&$ lang $=$ pt-br\&site $=$ ehost-live.

Gusmão, R., \& Xavier, M. (2005). O peso das perturbações depressivas: aspectos epidemiológicos globais e necessidades de informação em Portugal. Acta Médica Portuguesa, 18, 129-146. Retrieved from http://www.actamedicaportuguesa.com/revista/ index.php/amp/article/view/1012.

Hong, P. K., \& Heok, K. E. (2009). Economic crisis and mental health services in Asia. Asia-Pacific Psychiatry, 1(2), 55-57. doi:10.1111/j.1758-5872.2009.00016.x.

INE. (2014a). Estatísticas do Emprego: $1 .^{\circ}$ trimestre de 2014. Instituto Nacional de Estatística. Retrieved from http://www.ine.pt/ xportal/xmain?xpid=INE\&xpgid=ine_destaques\&DESTAQUE Sdestboui $=211340596 \&$ DESTAQUESmodo $=2$.

INE. (2014b). Taxa de mortalidade por lesões autoprovocadas intencionalmente (suicídio) por 100000 habitantes $\left(N .^{\circ}\right)$ por Local de residência (NUTS-2002), Sexo e Grupo etário. Anual (1). Retrieved from http://www.ine.pt/xportal/xmain?xpid=INE\&xp gid=ineindicadores\&indOcorrCod $=0003736 \&$ contexto $=$ bd \&sel $\mathrm{Tab}=\mathrm{tab} 2$.

INFARMED. (2014). Psicofármacos: Evolução do consumo em Portugal Continental (2000-2012), Lisboa. Retrieved from http:// www.infarmed.pt/portal/page/portal/lang-en/ver-1/INFARMED/ MONITORIZACAO_DO_MERCADO/OBSERVATORIO/ INTRODUCAO_DE_FICHEIROS/psicofarmacos_relatorio2013.pdf.

Jenkins, R. (1985). Sex differences in minor psychiatric morbidity. Psychological Medicine Monograph Supplement, 7, 1-53. Retrieved from http://search.ebscohost.com/login.aspx?direct $=\mathrm{tr}$ ue $\& \mathrm{db}=$ mdc $\& A N=3875115 \&$ lang $=$ pt-br\&site $=$ ehost-live .

Jenkins, R., Bhugra, D., Bebbington, P., Brugha, T., Farrell, M., Coid, J., ... Meltzer, H. (2008). Debt, income and mental disorder in the general population. Psychological Medicine, 38(10), 1485-1493. Retrieved from http://search.ebscohost. $\mathrm{com} /$ login. aspx ?direct $=$ true $\& \mathrm{db}=\mathrm{ccm} \& \mathrm{AN}=2010056284 \&$ lang $=$ pt-br\&site $=$ ehost-live.

Katikireddi, S. V., Niedzwiedz, C. L., \& Popham, F. (2012). Trends in population mental health before and after the 2008 recession: A repeat cross-sectional analysis of the 1991-2010 Health Surveys of England. BMJ Open. doi:10.1136/bmjopen-2012-001790.

Kovess-Masféty, V., Alonso, J., de Graaf, R., \& Demyttenaere, K. (2005). A European approach to rural-urban differences in mental health: The ESEMeD 2000 comparative study. Canadian Journal of Psychiatry. Revue Canadienne De Psychiatrie, 50(14), 926-936. Retrieved from http://search.ebscohost. com $/ \operatorname{login}$. aspx ?direct $=$ true $\& d b=$ mdc $\& A N=16494262 \&$ lang $=$ pt-br\&site $=$ ehost-live.

Laaksonen, E., Martikainen, P., Lahelma, E., Lallukka, T., Rahkonen, O., Head, J., \& Marmot, M. (2007). Socioeconomic circumstances and common mental disorders among Finnish and British public sector employees: Evidence from the Helsinki Health
Study and the Whitehall II Study. International Journal of Epidemiology, 36(4), 776-786. Retrieved from http://search.ebscohost.com/login. aspx $?$ direct $=$ true $\& d b=\operatorname{mdc} \& A N=17517811 \&$ la ng $=$ pt-br\&site $=$ ehost-live.

Lau, J. Y. F., \& Eley, T. C. (2010). The genetics of mood disorders. Annual Review of Clinical Psychology, 6, 313-337. doi:10.1146/ annurev.clinpsy.121208.131308.

Lewis, G., \& Sloggett, a (1998). Suicide, deprivation, and unemployment: Record linkage study. BMJ, 317(7168), 1283-1286. doi:10.1136/bmj.317.7168.1283.

Marmot, M. (2014). Review of social determinants and the health divide in the WHO European Region: Final report, Copenhagen. Retrieved from http://www.euro.who.int/_data/assets/pdf file/0004/251878/Review-of-social-determinants-and-the-healthdivide-in-the-WHO-European-Region-FINAL-REPORT.pdf.

Marmot, M. G., \& Bell, R. (2009). How will the financial crisis affect health?. BMJ (Clinical Research Ed.), 338, b1314-b1314. doi:10.1136/bmj.b1314.

Mathers, C. D., \& Schofield, D. J. (1998). The health consequences of unemployment: The evidence. The Medical Journal of Australia, 168(4), 178-182. Retrieved from http://search.ebscohost. com $/ \operatorname{login}$. asp $x$ ?direct $=$ true $\& d b=$ mdc $\& A N=9507716 \&$ lang $=$ pt-br\&site $=$ ehost-live.

McDaid, D., Quaglio, G., Correia de Campos, A., Dario, C., Van Woensel, L., Karapiperis, T., \& Reeves, A. (2013). Health protection in times of economic crisis: Challenges and opportunities for Europe. Journal of Public Health Policy, 34(4), 489-501. doi:10.1057/jphp.2013.35.

McKee-Ryan, F., Song, Z., Wanberg, C. R., \& Kinicki, A. J. (2005). Psychological and physical well-being during unemployment: A meta-analytic study. The Journal of Applied Psychology, 90(1), 53-76. Retrieved from http://search.ebscohost. com/login.aspx ?direct $=$ true $\& d b=$ mdc $\& A N=15641890 \&$ lang $=$ pt-br\&site $=$ ehost-live.

Munce, S. E. P., \& Stewart, D. E. (2007). Gender differences in depression and chronic pain conditions in a national epidemiologic survey. Psychosomatics, 48(5), 394-399. Retrieved from http://search.ebscohost.com/login.aspx?direct=true \&db=mdc\& $\mathrm{AN}=17878497$ \&lang $=$ pt-br\&site $=$ ehost-live.

Murphy, G. C., \& Athanasou, J. A. (1999). The effect of unemployment on mental health. Journal of Occupational \& Organizational Psychology, 72(1), 83-99. Retrieved from http://search. ebscohost.com/login. asp ?direct $=$ true $\& \mathrm{db}=\mathrm{ccm} \& \mathrm{AN}=2011316$ 869\&lang=pt-br\&site=ehost-live.

Nolen-Hoeksema, S. (1987). Sex differences in unipolar depression: Evidence and theory. Psychological Bulletin, 101(2), 259-282. Retrieved from http://search.ebscohost.com/login.aspx?direct=tr $\mathrm{ue} \& \mathrm{db}=$ mdc $\& A N=3562707 \&$ lang $=$ pt-br\&site $=$ ehost-live .

Observatório Português dos Sistemas de Saúde (OPSS). (2012). Crise \& Saúde: Um país em sofrimento. Relatório de Primavera 2012. Retrieved from http://www.observaport.org/sites/observaport. org/files/RelatorioPrimavera2012.pdf.

OECD. (2013). Health at a Glance 2013: OECD indicators. OECD Publishing. doi:10.1787/health_glance-2013-en.

OPSS. (2014). Saúde Síndroma de Negação: Relatório de Primavera 2014, Coimbra. Retrieved from http://www.observaport.org/ sites/observaport.org/files/RelatorioPrimavera2014.pdf.

Quaglio, G., Karapiperis, T., Van Woensel, L., Arnold, E., \& McDaid, D. (2013). Austerity and health in Europe. Health Policy (Amsterdam, Netherlands), 113(1-2), 13-19. doi:10.1016/j. healthpol.2013.09.005.

Reading, R., \& Reynolds, S. (2001). Debt, social disadvantage and maternal depression. Social Science \& Medicine (1982), 53(4), 441-453. Retrieved from http://search.ebscohost.com/ login.asp $\mathrm{x}$ ?direct $=$ true $\& \mathrm{db}=\mathrm{mdc} \& \mathrm{AN}=11459395 \&$ lang $=$ pt-br\&site $=$ ehost-live. 
Reeves, A., Stuckler, D., McKee, M., Gunnell, D., Chang, S. S., \& Basu, S. (2012). Increase in state suicide rates in the USA during economic recession. Lancet, 380(9856), 1813-1814. doi:10.1016/S0140-6736(12)61910-2.

Skapinakis, P., Weich, S., Lewis, G., Singleton, N., \& Araya, R. (2006). Socio-economic position and common mental disorders. Longitudinal study in the general population in the UK. The British Journal of Psychiatry: The Journal of Mental Science, 189, 109-117. Retrieved from http://search.ebscohost. com $/ \operatorname{login}$. asp $x$ ?direct $=$ true $\& d b=$ mdc $\& A N=16880479 \&$ lang $=$ pt-br\&site $=$ ehost-live.

Stuckler, D., Basu, S., Suhrcke, M., Coutts, A., \& McKee, M. (2011). Effects of the 2008 recession on health: A first look at European data. Lancet, 378(9786), 124-125. doi:10.1016/ S0140-6736(11)61079-9.

Sundquist, K., Frank, G., \& Sundquist, J. (2004). Urbanisation and incidence of psychosis and depression: Follow-up study of 4.4 million women and men in Sweden. The British Journal of Psychiatry: The Journal of Mental Science, 184, 293-298. Retrieved from http://search.ebscohost.com/login.aspx?direct=tr ue $\& \mathrm{db}=$ mdc $\& A N=15056572 \&$ lang $=$ pt-br\&site $=$ ehost-live.

Taylor, M. P., Pevalin, D. J., \& Todd, J. (2007). The psychological costs of unsustainable housing commitments. Psychological Medicine, 37(7), 1027-1036. Retrieved from http://search. ebscohost.com/login.aspx $?$ direct $=$ true $\& \mathrm{db}=\mathrm{ccm} \& \mathrm{AN}=2009624$ $123 \&$ lang $=$ pt-br\&site $=$ ehost-live.

Wang, J. L. (2004). Rural-urban differences in the prevalence of major depression and associated impairment. Social Psychiatry and Psychiatric Epidemiology, 39(1), 19-25. Retrieved from http:// search.ebscohost.com/login.aspx?direct $=$ true $\& \mathrm{db}=\mathrm{mdc} \& \mathrm{AN}=1$ 5022042\&lang $=$ pt-br\&site $=$ ehost-live.

Weissman, M. M., \& Klerman, G. L. (1977). Sex differences and the epidemiology of depression. Archives of General Psychiatry, 34(1), 98-111. Retrieved from http://search.ebscohost. com $/ \operatorname{login}$. asp $x$ ?direct $=$ true $\& d b=$ mdc $\& A N=319772 \&$ lang $=$ pt-br\&site $=$ ehost-live.

WHO. (2011). Impact of economic crises on mental health.

WHO. (2013). Health, health systems and economic crisis in Europe: Impact and policy implications. Zhurnal Eksperimental'noi $i$ Teoreticheskoi Fiziki. Retrieved from http://www.euro.who. int/_data/assets/pdf_file/0011/186932/Health-and-economiccrisis-in-Europe4.pdf?ua=1.

Xavier, M., Baptista, H., Mendes, J. M., Magalhães, P., \& Caldas-deAlmeida, J. M. (2013). Implementing the World Mental Health Survey initiative in Portugal: Rationale, design and fieldwork procedures. International Journal of Mental Health Systems, 7(1), 19. doi:10.1186/1752-4458-7-19. 